\title{
HUBUNGAN PERILAKU IBU TERHADAP PEMELIHARAAN KESEHATAN GIGI ANAK DENGAN KEJADIAN EARLY CHILDHOOD CARIES (ECC) PADA ANAK PENDIDIKAN USIA DINI (PAUD) DI WILAYAH KERJA PUSKESMAS ANDALAS KECAMATAN PADANG TIMUR KOTA PADANG
}

\author{
Wulandani Liza Putri ${ }^{1}$, Febrian $^{2}$ \\ ${ }^{1}$ Faculty of Dentistry Andalas University \\ . ${ }^{2}$ Departemen of Dental Public Health Faculty of Dentistry Andalas University
}

\begin{abstract}
Early Childhood Caries (ECC) is dental disease in preschool children that becomes a huge problem whole the world. In USA, prevalence of ECC is $41 \%$ and $90 \%$ in Indonesia, but actually WHO Oral Health Goal decided $90 \%$ of children must have to be caries free. One of risk factor of ECC in preschooler is mothers behavior. The aim of this research is to provide relationship between mothers behavior toward oral health maintenance and ECC among preschool children of informal education in Andalas Social Health Centre working area East Padang Subdistrict Padang City.This research used cross sectional study design. Samples were preschool children of informal education and respondents were their mothers amount 81 people. Preschoolers underwent a comprehensive dental examination while mothers were investigated used questionnaire that explored knowledge, attitudes, and behavior toward preschool oral health maintenance. Statistic analysis of this research were univariat analysis and bivariat analysis used chi-square test and $p<0,05$. The result indicates that $79 \%$ children suffered from ECC, mothers knowledge of $91,4 \%$ in high category, mothers attitudes of $48,1 \%$ in negative category, and mothers behavior was in bad category of 43,2\% toward oral health maintenance. There is no relationship between mothers behavior toward oral health maintenance and ECC.Suggested to health workers to do preschool children dental screening periodically and give dental health education to mothers who have preschool children so that ECC can be decreased.
\end{abstract}

Keywords: Mothers' behavior, Dental Health Maintenance, ECC

\section{PENDAHULUAN}

Salah satu masalah kesehatan gigi yang terbesar yang dialami masyarakat adalah karies gigi. Karies gigi tidak hanya menjadi masalah di Indonesia, akan tetapi juga menjadi masalah yang masih belum terpecahkan secara tuntas di dunia. Hal ini terkait dengan masih tingginya prevalensi karies gigi di berbagai negara. Di negara- negara Eropa dan Amerika, 80-90\% anakanak di bawah umur 18 tahun menderita karies gigi sedangkan di Indonesia prevalensi karies gigi adalah $90,05 \% .{ }^{1}$ Karies gigi tidak hanya terjadi pada orang dewasa, tetapi juga terjadi pada anak-anak. Karies gigi yang terjadi pada anak-anak usia prasekolah disebut 
Early childhood caries (ECC). Menurut Center for Disease Controland Prevention, penyakit ini menyerang bayi dan anak-anak usia prasekolah di seluruh dunia dan menjadi masalah kesehatan yang serius di negara-negara berkembang maupun negara-negara maju. ${ }^{2}$

Menurut American Academy of Pediatric Dentistry (AAPD) tahun 2009, di negara maju seperti Amerika Serikat, prevalensi ECC pada anak adalah $41 \%$ dan menyerang 1 dari 7 anakusia prasekolah di California. ${ }^{2,3} \mathrm{Di}$ negara-negara berkembang, prevalensinya lebih tinggi. Ini terbukti dari data Antara news tanggal 31 januari 2005 bahwa di Indonesia prevalensi karies gigi pada anak adalah 90\% pada tahun 2000an. Angka ini masih jauh dari WHO Oral Health Goal yaitu 90\% anak bebas karies pada usia ini. ${ }^{1}$

Menurut American Academy of Pediatric Dentistry pada tahun 2010, ECC diartikan adanya satu atau lebih karies gigi, hilangnya gigi (karena karies), dan/atau gigi ditambal (karena karies), pada anak usia di bawah 72 bulan. ${ }^{2}$ Pada awalnya, istilah ECC disamakan dengan Nursing Bottle Caries atau karies susu botol yang terjadi akibat kecenderungan anak menyusu dengan botol saat tidur di malam hari. Akan tetapi, Center for Disease Control and Prevention menunjukkan bahwa penggunaan susu botol bukanlah penyebab ECC satu- satunya. ${ }^{4}$ Penelitian yang dilakukan oleh Schroth tahun 2007 juga mendukung pernyataan tersebut dan menyebutkan bahwa ECC merupakan penyakit multifaktorial yang dipengaruhi oleh sosioekonomi, kebiasaan, psikososial, dan lain- lain. ${ }^{5}$

ECC terjadi pada usia prasekolah, yaitu sebelum usia 72 bulan. Pada usia ini, sebagian anak sudah mulai masuk Pendidikan Anak Usia Dini (PAUD). Di PAUD anak diajar berkomunikasi dan menerima instruksi, terutama oleh guru, sehingga guru sebagai pendidik juga diharapkan dapat memberikan edukasi ringan seputar pemeliharaan mulut pada anak dan ibuanak.Perilaku ibu juga sangat berpengaruh terhadap kesehatan gigi anak. Hal ini dibuktikan oleh hasil penelitian Poutanen R. et al pada tahun 2006 di Finlandia yang menunjukkan bahwa Ibu dengan perilaku kesehatan gigi yang baik memiliki anak dengan kesehatan gigi dan mulut yang lebih baik daripada ibu dengan dengan perilaku yang kurang baik. ${ }^{6}$

Di Indonesia penelitian serupa juga telah dilakukan oleh Lina Natamiharja pada tahun 2010 di Medan dan juga menyatakan bahwa prevalensi bebas karies lebih tinggi pada ibu dengan perilaku kesehatan gigibaikdaripada ibu dengan perilaku sedang dan kurang. ${ }^{7}$ Di Sumatera Barat, Nindra juga telah melakukan penelitian di kota Solok pada 
tahun 2009 dan juga menunjukkan bahwa perilaku ibu berkaitan dengan tingkat pengetahuan, sikap dan tindakan ibu terhadap pencegahan karies gigi pada anak. ${ }^{8}$ Berdasarkan hal di atas, peneliti tertarik untuk mengetahui hubungan perilaku ibu terhadap pemeliharaan kesehatan gigi anak dengan kejadian ECCpada siswaPAUD di kecamatan Padang Timur.

\section{MATERI DANMETODE}

Kajian dalam penelitian ini adalah melihat hubungan perilaku ibu tentang pemeliharaan kesehatan gigi anak yang mengalami ECC pada anak PAUD yang dilakukan dengan metode cross sectional. Penelitian ini dilakukan pada siswa PAUD di di wilayah kerja Puskesmas Kecamatan Padang Timur.Pengambilan sampel dilakukan dengan metode proportional random sampling. Caranya pertama adalah memilih 5 dari 11 sekolah PAUD secara acak dengan undian kemudian pada sekolah PAUD terpilihdiambil sampelnya secara proporsional

Analisis dilakukan dengan cara univariat dan bivariat. Analisis univariat untuk mengetahui gambaran pengetahuan, sikap, dan tindakan ibu terhadap pemeliharaankesehatangigi anak dan analisis bivariat dilakukan untuk melihat hubungan antara dua variabel, yaitu variabel terikat dan variabel bebas yaitu melihat hubungan antara pengetahuan, sikap, dan tindakan ibu terhadap pemeliharaan kesehatan gigi anak dengan kejadian ECC menggunakanchi-square test.Hubungan dua variabel dinyatakan dengan nilai $p$, bila $p<0,05$ berarti hubungan bermakna.

\section{HASIL}

Hasil dari analisis univariat di dapat hasil sebagai berikut:

Tabel 1.Distribusi kejadianECC pada Siswa PAUD

\begin{tabular}{lcc}
\hline Kejadian ECC & $\mathbf{n}$ & $\%$ \\
\hline ECC & 64 & 79 \\
Tidak ECC & 17 & 21 \\
\hline Jumlah & 81 & 100 \\
\hline
\end{tabular}

Dari tabel 1 dapat diketahui $79 \%$ sampel anak PAUD yang di periksa merupakan anak yang mengalami ECC

Tabel 2.Distribusi tingkat Pengetahuan Ibu tentang pemeliharaan kesehatan gigi anakdalam Pemeliharaan Kesehatan Gigi anak

\begin{tabular}{lcc}
\hline $\begin{array}{c}\text { Tingkat } \\
\text { Pengetahuan }\end{array}$ & n & \% \\
\hline Rendah & 7 & 8,6 \\
Tinggi & 74 & 91,4 \\
\hline Jumlah & $\mathbf{8 1}$ & $\mathbf{1 0 0}$ \\
\hline
\end{tabular}

Dari tabel 2 diketahui 91,4\% ibu memiliki pengetahuan yang tinggi tentang pemeliharaan kesehatan gigi anak

Tabel 3.Distribusi frekuensi Sikap Ibu dalam Pemeliharaan Kesehatan Gigi Anak PAUD 


\begin{tabular}{lcc}
\hline \multicolumn{1}{c}{ Sikap } & n & \% \\
\hline Negatif & 39 & 48,1 \\
Positif & 42 & 51,9 \\
\hline Jumlah & $\mathbf{8 1}$ & $\mathbf{1 0 0}$ \\
\hline
\end{tabular}

Dari tabel 3 diketahui 51,9 ibu memiliki sikap yang positif dalam pemeliharaan gigi anak anaknya

Tabel 4 Distribusi Tindakan Ibu dalam Pemeliharaan Kesehatan Gigi Anak PAUD

\begin{tabular}{lcc}
\hline Tindakan & n & $\%$ \\
\hline Kurang Baik & 35 & 43,2 \\
Baik & 46 & 56,8 \\
\hline Jumlah & 81 & 100 \\
\hline
\end{tabular}

Dari tabel 4 diketahui 43,2 \% ibu memiliki tindakan yang kurang baik untuk pemeliharaan kesehatan gigi anaknya

Dari AnalisaBivariat dapat di lihat

Tabel 5 Hubungan TingkatPengetahuanIbu dalam Pemeliharaan Kesehatan Gigi Anakdengan Kejadian ECCpada anak Siswa PAUD

\begin{tabular}{|c|c|c|c|c|c|c|c|}
\hline \multirow{3}{*}{$\begin{array}{l}\text { Tingkat } \\
\text { Pengètahuan }\end{array}$} & \multicolumn{4}{|c|}{ Kejadian $E C C$} & \multirow{2}{*}{\multicolumn{2}{|c|}{ Jumlah }} & \multirow{3}{*}{ P-value } \\
\hline & \multicolumn{2}{|c|}{$E C C$} & \multicolumn{2}{|c|}{ Tidak $E C C$} & & & \\
\hline & $\mathrm{n}$ & $\%$ & $\mathrm{n}$ & $\%$ & $\mathrm{n}$ & $\%$ & \\
\hline Rendah & 5 & 71,4 & 2 & 28,6 & 40 & 100 & \\
\hline Tinggi & 59 & 79,7 & 15 & 20,3 & 41 & 100 & 0,633 \\
\hline Total & 64 & & 17 & & 81 & & \\
\hline
\end{tabular}

Dari tabel 5 dapat di ketahui tidak terdapat hubungan yang bermakna antara Tingkat Pengetahuan Ibu tentang pemeliharaan gigi anak dengan Kejadian ECC pada anak Siswa PAUD dengan nilai P-
Value $0,633>0,05$

Tabel 6. Hubungan Sikap Ibu terhadap Pemeliharaan Kesehatan Gigi Anak dengan Kejadian Early Childhood Caries pada Siswa PAUD

\begin{tabular}{|c|c|c|c|c|c|c|}
\hline \multirow{3}{*}{ Sikap } & \multicolumn{4}{|c|}{ Kejadian $E C C$} & \multirow{2}{*}{ Jumlah } & \multirow{3}{*}{ P-value } \\
\hline & \multicolumn{2}{|c|}{$E C C$} & \multicolumn{2}{|c|}{ Tidak $E C C$} & & \\
\hline & $\mathrm{n}$ & $\%$ & $\mathbf{n}$ & $\%$ & n $\%$ & \\
\hline Negatif & 33 & 82,5 & 7 & 17,9 & $40 \quad 100$ & \\
\hline Positif & 31 & 75,6 & 10 & 23,8 & $41 \quad 100$ & 0,625 \\
\hline Total & 64 & 79 & 17 & 21 & $81 \quad 100$ & \\
\hline
\end{tabular}

Dari tabel 6 dapat di ketahui tidak terdapat hubungan yang bermakna antara sikap ibu tentang pemeliharaan gigi anak dengan kejadian ECCpada anak SiswaPAUD dengan nilai P-Value 0,625>0,05

Tabel 7. Hubungan Tindakan Ibu dalam Pemeliharaan Kesehatan Gigi Anak dengan Kejadian Early Childhood Cariespada Siswa PAUD

\begin{tabular}{|c|c|c|c|c|c|c|c|}
\hline \multirow{3}{*}{ Tindakan } & \multicolumn{4}{|c|}{ Kejadian ECC } & \multirow{2}{*}{\multicolumn{2}{|c|}{ Jumlah }} & \multirow{3}{*}{$p$ value } \\
\hline & \multicolumn{2}{|c|}{$E C C$} & \multicolumn{2}{|c|}{ Tidak $E C C$} & & & \\
\hline & $\mathbf{n}$ & $\%$ & $\mathbf{n}$ & $\%$ & $\mathbf{n}$ & $\%$ & \\
\hline Kurang Baik & 31 & 88,6 & 4 & 11,4 & 35 & 100 & \\
\hline Baik & 33 & 71,7 & 13 & 28,3 & 46 & 100 & 0,117 \\
\hline Jumlah & 64 & 79 & 17 & 21 & 81 & 100 & \\
\hline
\end{tabular}

\section{PEMBAHASAN}

KejadianECC

Berdasarkan hasil pemeriksaan yang dilakukan sebagian besar siswa PAUD (79\%) di Kecamatan Padang Timur, mengalami ECC. Hasil penelitian ini lebih tinggi dari hasil penelitian Schroth 2006 di Canada dimana 53,7\% anak mengalami 
ECC. ${ }^{5}$ Hal ini disebabkan karena ada perbedaan wilayah, dimana Indonesia masih negara sedang berkembang sedangkan Canada adalah negara maju karena menurut pendapat Suwelo 1992 karies lebih banyak terjadi pada negara berkembang. ${ }^{9}$

\section{Tingkat Pengetahuan Ibu tentang Pemeliharaan Kesehatan Gigi Anak}

Berdasarkan hasil penelitian, mayoritas ibu $(91,4 \%)$ memiliki pengetahuan tinggi tentang pemeliharaan kesehatan gigi anak. Hasil ini lebih tinggi daripada hasil penelitian Zulfitriani di taman kanak kanak desa Cijantang kota Sawahlunto tahun 2008, hanya $32,4 \%$ orangtua siswa yang mempunyai pengetahuan tinggi tentang pemeliharaan kesehatan gigi anak. Perbedaan hasil ini dapat disebabkan oleh perbedaan lokasi penelitian. Penelitian ini dilakukan di Kota Padang yang merupakan ibu kota provinsi yang relatif lebih maju sehingga lebih banyak mendapat informasi mengenai pemeliharaan kesehatan. ${ }^{10}$

\section{Sikap Ibu terhadap Pemeliharaan Kesehatan Gigi Anak}

Berdasarkan hasil penelitian diketahui bahwa lebih dari separuh ibu (51,9\%) memiliki sikap yang positif terhadap pemeliharaan kesehatan gigi anak. Hasil ini sejalan dengan penelitian yang dilakukan oleh Yulzi Emmi yang mendapatkan hasil ibu dengan sikap positif $(60,6 \%)$ lebih banyak daripada ibu dengan sikap negatif. Hal ini dapat disebabkan oleh adanya persamaan tingkat pendidikan ibu, yaitu sebagian besar ibu berpendidikan SMA. ${ }^{8}$

Menurut Newcomb, seorang ahli psikologi, sikap merupakan kesiapan atau kesediaan untuk bertindak dan bukan merupakan pelaksanaan motif tertentu. Dalam membentuk sikap maka pengetahuan, pikiran, keyakinan, dan emosi memegang peranan penting. Oleh karena itu pengetahuan tentang pemeliharaan kesehatan gigi anak harus ditingkatkan. ${ }^{11}$

\section{Tindakan Ibu dalam Pemeliharaan Kesehatan Gigi Anak}

Berdasarkan hasil penelitian diketahui bahwa kurang dari separuh ibu $(43,2 \%)$ memiliki tindakan yang kurang baik. Hasil ini lebih rendah dibandingkan dengan hasil penelitian Nindra di kota Solok tahun 2009 yang menyatakan bahwa lebih dari separuh orangtua memiliki tindakan kurang baik (68,3\%). Hal ini dapat disebabkan oleh perbedaan karakteristik responden yang berbeda seperti tingkat pendidikan responden. Sebagian besar responden pada penelitian ini berpendidikan SMA sedangkan pada penelitian Nindra yang dilakukan di Kota 
Solok sebagian besar respondennya memiliki pendidikan terakhir SMP. ${ }^{12}$

\section{Hubungan Tingkat Pengetahuan Ibu tentang Pemeliharaan Kesehatan Gigi Anak dengan Kejadian $E C C$}

Hasil penelitian menunjukkan bahwa anak dari ibu yang tingkat pengetahuannya tinggi lebih banyak yang mengalami ECC daripada ibu dengan tingkat pengetahuan rendah. Berdasarkan hasil uji statistik dari penelitian ini didapatkan nilai $\mathrm{p}>0,05$ sehingga dapat disimpulkan bahwa tidak ada hubungan yang bermakna antara tindakan ibu dalam pemeliharaan kesehatan gigi anak dengan kejadian $E C C$. Penelitian initidak sejalan dengan penelitian Natamiharja dan Dwi di Kota Medan tahun 2010 yang mendapatkan hubungan bermakna antara tingkat pengetahuan ibu dengan def-t balita. ${ }^{7}$ Akan tetapi penelitian ini sejalan dengan penelitian Mc Kinney di Karolina Selatan yang tidak mendapatkan hubungan antara pengetahuan orangtua dengan kejadian ECC. ${ }^{13}$

Lebih tingginya $E C C$ pada ibu dengan pengetahuan tinggi dapat disebabkan oleh faktor lain seperti pengetahuan yang tidak didukung oleh tindakan yang baik. Selain itu, dapat juga disebabkan oleh kurangnya kontrol ibu terhadap tindakan anak yang dapat menyebabkan terjadinya $E C C$ selama ibu bekerja karena ibu dengan pengetahuan tinggi cenderung mempunyai pendidikan tinggi dan bekerja di luar rumah.Ibu dengan pengetahuan rendah dan bekerja sebagai ibu rumah tangga lebih memiliki waktu bersama anak sehingga dapat mengontrol tindakan anak dengan lebihbaik.

\section{Hubungan Sikap Ibu terhadap Pemeliharaan Kesehatan Gigi Anakdengan Kejadian $\boldsymbol{E C C}$}

Berdasarkan hasil penelitian, didapatkan ibudengan sikap yang negatif mempunyai anak dengan kejadian ECC lebih tinggi daripada ibu dengan sikap positif terhadappemeliharaan kesehatan gigi anak. Dari hasil uji statistik didapatkan $p>0,05$ sehingga dapat disimpulkan bahwa tidak ada hubungan yang bermakna antara sikap ibu terhadap pemeliharaan kesehatan gigi anak dengan kejadian ECC. Hasil penelitian ini tidak sejalan dengan penelitian Mardiati di Kota Semarang tahun 2006 yang mendapatkan hubungan bermakna antara sikap ibu terhadap pemeliharaan kesehatan gigi anak dengan kejadian karies gigi anak. ${ }^{14}$

Penelitian Skeie et al di Norwegia tahun 2002-2004 juga menunjukkan hubungan yang bermakna antara sikap ibuterhadap pemeliharaan kesehatan gigi anak dengan kejadian ECC. Tidak terdapatnya hubungan antara sikap ibu dengan kejadian ECC juga dapat 
disebabkan oleh sikap ibu yang tidak diwujudkan menjadi tindakan. Selain itu juga dapat disebabkan oleh sikap ibu yang didasari kebiasaan/tradisi, bukan pengetahuan. Sebagian besar ibu tidak setuju untuk menutup gigi anak yang berlubang dengan kapas dan minyak cengkeh karena tidak ada kebiasaan di dalam keluarga mereka, bukan karena mengetahui ada atau tidaknya manfaat penggunaan minyak cengkehtersebut. ${ }^{15}$

\section{Hubungan Tindakan Ibu dalam Pemeliharaan Kesehatan Gigi Anakdengan Kejadian ECC}

Hasil penelitian menunjukkan bahwa ibu dengan tindakan yang kurang baik mempunyai anak dengan kejadian ECC lebih tinggi dari pada ibu dengan tindakan yang baik dalam pemeliharaan kesehatan gigi anak. Berdasarkan hasil uji statistik didapatkan $p>0,05$ sehingga dapat disimpulkan bahwa tidak ada hubungan yang bermakna antara tindakan ibu dalam pemeliharaan kesehatan gigi anak dengan kejadian ECC. Hasil penelitian ini tidak sejalan dengan hasil penelitian Yulzi Emmi yang mendapatkan hubungan bermakna antara tindakan orangtua dengan kejadian karies gigi anak. ${ }^{8}$

Baiknya tindakan ibu yang tidak berhubungan dengan kejadian ECC dapat disebabkan oleh faktor lain yang tidak diperhitungkan seperti tindakan anak. Sebagian besar ibu mengaku anaknya sudah bisa membeli jajanan sendiri yang tidak terkontrol oleh ibu sehingga baiknya tindakan ibu yang tidak didukung oleh baiknya tindakan anak akan dapat menyebabkan ECC. Selain itu, tindakan ibu yang dilakukan belum tentu dilakukan dengan benar seperti cara menyikat gigi anak.

\section{KESIMPULAN DAN SARAN}

Sebagian besar siswa PAUD di Kecamatan Padang Timur mengalami ECC.Hampir seluruh ibu memiliki tingkat pengetahuan yang tinggi tentang pemeliharaan kesehatan gigianak namun Hampir separuh ibu memiliki sikap yang negatif dan tindakan yang buruk terhadap pemeliharaan kesehatan gigi anak

Tidak ada hubungan antara tingkat pengetahuan ibu, sikap ibu dan tindakan ibu tentang pemeliharaan kesehatan gigi anak dengan kejadian Early Childhood Caries pada siswa PAUD di Kecamatan Padang Timur namun karena tingginya angka ECCpada siswa PAUD maka di sarankan

1. Pihak Posyandu diharapkan rutin melakukan pemeriksaan kesehatan gigi anak secara berkala agar dapat diketahui peningkatan atau penurunan kejadian ECC sehingga dapat digunakan sebagai bahan evaluasi program kesehatan gigi khususnya pada anak usia dini.

2. Sekolah PAUD dapat memberikan edukasi ringan kepada siswa tentang 
pentingnya menjaga kebersihan gigi. Pihak PAUD diharapkan untuk menyelipkan materi seputar kesehatan gigi dalam materi pembelajaran utama agar anak termotivasi dari usia dini untuk memelihara kesehatan giginya. Dengan ini diharapkan akan menjadi kebiasaan hingga anak dewasa.

3. Bagi Ibu perlu mengontrol gigi anaknya setiap 6 bulan sekali ke puskesmas/dokter gigi meskipun tidak ada keluhan sakit gigi pada anak

\section{KEPUSTAKAAN}

1. Sonya Y. Hubungan Pengetahuan, Sikap, dan Kebiasaan Menggosok Gigi dengan Kejadian Karies Gigi pada Murid SDN 23 Kubu Marapalam Kota Padang Tahun 2010. Padang: Universitas Andalas.2010.

2. Marrs, Jo-Ann, Sharon T, Gaurav M. Early Childhood Caries: Determining the Risk Factors and Assessing the Prevention Strategies forNursing Intervention.Pediatric nursing. 2011;(3):1

3. Platt, J.Laurence. Early Childhood Dental Caries. UCLA center for healthier children, families, and communities.2000.

4. Kumar, Dhruva V. Early Childhood Cariesan Insight. Journal of International Oral Health. 2010.

5. Schroth, Robert J, Douglas J Brothwell, Michael EK Moffat..Caregiver Knowledge and Attitudes Of Preschool Oral Health and Early Childhood Caries (ECC). International Journal of Circumpolar Health. 2007; (66): 2.

6. R. Poutanen, Lahti S, TolvanenM, Hausen H. 2006. Parental Influence on Children's Oral Health-Related Behavior. Oulu, Finland: Acta Odontal Scand. 2006; 64 (5): 286-92.
7. Natamiharja L, Dewi NS. Hubungan Pendidikan, Pengatahuan, dan Perilaku Ibu terhadap Status Karies Gigi Balitanya. Medan: Dentika dental journal. 2010; 15:3741.

8. Emmi, Y. Hubungan Perilaku Orangtua dalam Pemeliharaan Kesehatan Gigi Anak dengan Kejadian Karies Gigi di SDN 09 Surau Gadang Kecamatan Nanggalo Kota Padang Tahun 2010. Padang: UniversitasAndalas. 2010.

9. Suwelo, S.I. Karies Gigi pada Anak dengan Berbagai Faktor Etiologi. Jakarta EGC.1992.

10. Zulfiriani. Gambaran Tingkat Pengetahuan dan Sikap Orangtua Murid Taman KanakKanak Kasih Ibu Desa Cijantang tentang Kesehatan Gigi di Wilayah Kerja Puskesmas Talawi Kodya Sawahlunto Tahun 2008. Padang: Poltekes.2008.

11. Notoadmodjo S. Promosi Kesehatan dan Ilmu Perilaku. Jakarta: Rineka Cipta. 2007.

12. Nindra A. Hubungan Perilaku Orangtua tentang Pemeliharaan Kesehatan Gigi Anak dengan Kejadian Karies Gigi Susu di SD 06 Tanah Garam Kota Solok Tahun 2009. Padang: UniversitasAndalas. 2009.

13. Mc Kinney, Voronina. The Relationship between Early Childhood Caries and Caregivers Oral Healthknowledge and Behavior among Medicaid-Eligible Children in North Carolina. North Carolina.2002.

14. Mardiati E. Hubungan Pengetahuan, Sikap, dan Praktik Ibu Petani dengan Karies Gigi dan Radang Gusi Anak Usia 6-8 Tahun di Kelurahan Nongkosawit Kota Semarang.Semarang: 2006.

15. Skeie, Marit, Espelid I, Riordan PJ, Klock KS. Caries Increment in Children Aged 3-5 Years in Relation to Parents' Dental Attitudes. Oslo, Norwegia.. 2002-2004 